\title{
Huge scalp Morel-Lavallée lesion with eye involvement in a 3-year-old girl: a case report
}

\author{
Claude Kasereka Masumbuko ${ }^{1}$, Gabriel Kambale Bunduki ${ }^{2^{*}}$ (D) and Mupenzi Mumbere ${ }^{3}$
}

\begin{abstract}
Background: Morel-Lavallée lesions are posttraumatic, closed degloving injuries in which the skin and subcutaneous tissue are separated abruptly from superficial underlying fascia. This condition leads to an effusion containing hemolymph and necrotic fat. Magnetic resonance imaging, when available, is the modality of choice in the evaluation of Morel-Lavallée lesion. Early diagnosis and management is essential as any delay in diagnosis or missed lesion will lead to the effusion becoming infected or leading to extensive skin necrosis. We present a condition of a Morel-Lavallée lesion involving the scalp and complicated by conjunctival chemosis.

Case presentation: We report on a 3-year-old black African girl who presented a fluctuant swelling of entire scalp, extending to upper part of the face on the seventh day after a forehead trauma due to falling on a rock while playing. Skull $x$-ray revealed soft-tissue swelling, giving an impression of large fluid collection in the deep subcutaneous tissues with no bone fracture. A diagnosis of Morel-Lavallée lesion of the scalp complicated by conjunctival chemosis was made. The patient was managed with percutaneous drainage and compression bandage. The patient improved well and was subsequently discharged without any vision impairment. There was no recurrence of the lesion on follow-up.

Conclusions: The Morel-Lavallée lesion of the scalp complicated with conjunctival chemosis is a rare presentation of this condition. Prompt diagnosis and management are crucial for preventing complications. Image-guided diagnosis and treatment still remain a challenge in the setting of low-resource health facilities.
\end{abstract}

Keywords: Closed degloving injury, Morel-Lavallée lesion, Eye, Scalp, Conjunctival chemosis, Case report

\section{Background}

Morel-Lavallée lesion (MLL), first described in 1853, is a closed degloving soft tissue injury, a result of abrupt separation of skin and subcutaneous tissue from the underlying fascia [1]. In this condition, there is collection of hemolymphatic liquid in between the two separated layers [2]. Initially, MLL was used in reference to injuries involving the trochanteric region and proximal thigh. However, in recent years, this term has been used for describing lesions with similar pathophysiology in various anatomical locations [3]. MLL diagnosis

\footnotetext{
*Correspondence: gabriel.bunduki@gmail.com

2 Department of Infectious Diseases, Faculty of Medicine, Université

Catholique du Graben, Butembo, Democratic Republic of Congo

Full list of author information is available at the end of the article
}

is mainly based on clinical features and should be taken into account in every traumatic setting. Suspicion should arise in the case of localized swelling, especially with fluctuation. After clinical suspicion, imaging investigations should be performed. Magnetic resonance imaging (MRI) is the modality of choice for investigation of MLL [4]. To prevent infection or extensive skin necrosis as complications, early diagnosis and management of the lesion is critical.

Here we report a rare presentation of MLL involving the scalp complicated by conjunctival chemosis in a 3 -year-old girl. To our knowledge, this is the first case of MLL with eye involvement reported in the literature.

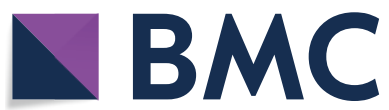

(c) The Author(s) 2021. Open Access This article is licensed under a Creative Commons Attribution 4.0 International License, which permits use, sharing, adaptation, distribution and reproduction in any medium or format, as long as you give appropriate credit to the original author(s) and the source, provide a link to the Creative Commons licence, and indicate if changes were made. The images or other third party material in this article are included in the article's Creative Commons licence, unless indicated otherwise in a credit line to the material. If material is not included in the article's Creative Commons licence and your intended use is not permitted by statutory regulation or exceeds the permitted use, you will need to obtain permission directly from the copyright holder. To view a copy of this licence, visit http://creativecommons.org/licenses/by/4.0/. The Creative Commons Public Domain Dedication waiver (http://creativeco mmons.org/publicdomain/zero/1.0/) applies to the data made available in this article, unless otherwise stated in a credit line to the data. 


\section{Case presentation}

A 3-year-old black African female was brought to our emergency room with trauma to the forehead and history of fall on a rock while playing. There was a delay of 7 days between the trauma and presentation to the health facility. No history of loss of consciousness was mentioned. Admitted to a nearby medical facility, the daily increase of head circumference with the protrusion of eyeballs and eye watering motivated the facility to refer the patient. On clinical examination, she had palpebral conjunctiva protrusion, fluctuant swelling of entire scalp extending to upper part of the face (Fig. 1). There was no skin necrosis. Skull $\mathrm{x}$-ray demonstrated soft tissue swelling, giving an impression of a large fluid collection in the deep subcutaneous tissue with no bone fracture observed. Ultrasound (US) of the fluctuant swelling in the scalp was difficult to conduct. No MRI machine was available. Ophthalmologic examination revealed conjunctival chemosis and blurred vision. Laboratory tests revealed the manifestations of infected lesions [hemoglobin level of $7 \mathrm{mg} / \mathrm{dl}$ and white blood cells (WBC) count of $29,800 / \mathrm{mm}^{3}$. The diagnosis of Morel-Lavallée lesion with conjunctival chemosis was established. The patient received two pints of packed red blood cell (PRBC) transfusion and ceftriaxone $350 \mathrm{mg}$ intravenously twice a day. She was also managed with percutaneous drainage and compression bandage (Figs. 2, 3). The lesion subsided at the time of discharge with full visual capacity recovery. There was no recurrence of the lesion on follow-up.

\section{Discussion and conclusions}

The diagnosis of MLL is challenging owing to its inconsistent clinical presentation and the initial involvement of skin bruising due to underlying soft-tissue injury. Clinical presentation varies according to the amount of hemolymphatic liquid collected at the site of injury and the time elapsed since the injury $[2,5]$. The symptoms include soft-tissue swelling giving the impression of a soft fluctuant area, cutaneous sensation decreased, skin hypermobility, contour deformity, palpable bulge, etc. [6] In our case, these symptoms were extended to both eyes, giving conjunctival chemosis. Several published studies have reported cases of MLL involving lumbar area, hip,

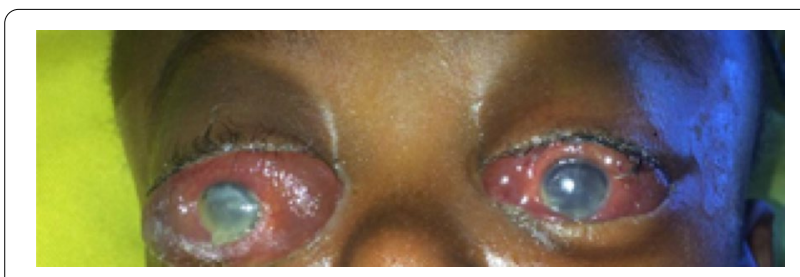

Fig. 1 Fluctuant swelling in eye and scalp

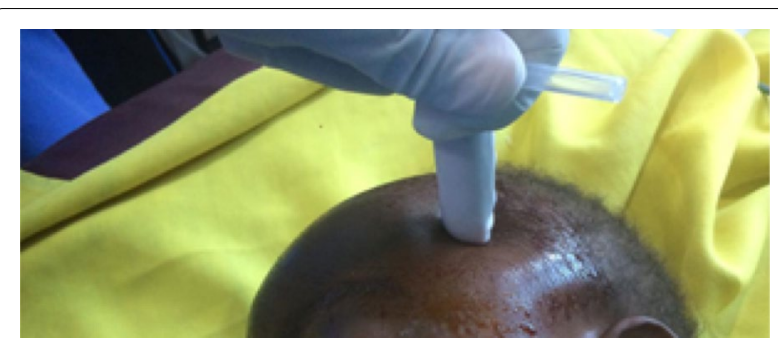

Fig. 2 Drainage of the hemolymphatic liquid

and inferior members [7-9], though none has described MLL with eye involvement. To our knowledge, this is the first reported case in the literature.

Since diagnosis of MLL is challenging owing to inconsistent clinical presentation, imaging investigations are very useful. Radiological findings are characterized by the presence of nonspecific and noncalcified soft-tissue mass. Meanwhile, US scan may reveal hyperechoic (blood-predominant) or anechoic (lymph-predominant) images depending on the age and predominant content of the lesion. A heterogeneous image with irregular margins and lobular shape may be seen in lesions less than 1 month old. For lesions older than 1 month, a homogeneous image with smooth margins and flat or fusiform shape may be seen. MRI scan shows soft-tissue contrast enhancement $[4,10]$. Hence, it is the modality of choice in the evaluation of MLL. Due to financial constraints and lack of equipment such as MRI in our setting, the diagnosis was done on the basis of clinical and skull $x$-ray assessment.

In this case, the conjunctival chemosis and blurred vision may be explained by the conjunctival and probably corneal infiltration of swelling and the inflammatory reaction. To the best of our knowledge, this is the first case of MLL of scalp with eye involvement reported in the literature.

This case was managed with percutaneous drainage and compression bandage. An antibiotic therapy was added to this approach. Currently, there is no accepted

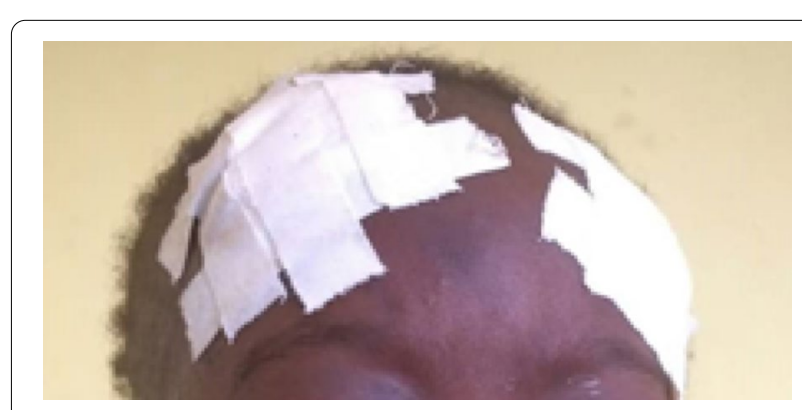

Fig. 3 Patient with the compression bandage 
management approach for MLL. A variety of conservative and surgical options exist. This may be a stage-based or an individualized management approach. Objectives of management include drainage of the hemolymphatic liquid for resolving the contour deformity and allowing the apposition of lesion walls, debridement for removing necrotic tissues or mature capsule in chronic lesions, and meticulous dead space management to prevent recurrence by facilitating long-term adhesion of lesion walls either by fibrosis or using surgical apposition techniques $[11,12]$. In addition to that, a definitive management of associated injuries should be done.

Recently, a new management algorithm was proposed and appeared to be a rational approach [11]. It recommends the distinction of lesions into acute and chronic. An absolute surgical exploration is indicated in the case of acute MLL with open fracture associated with lesion, skin necrosis, and infection. This approach may also be indicated in the case of failure of nonsurgical approach, in chronic symptomatic lesions, and when the lesion is in association with a closed fracture requiring open fixation [11]. Complications associated with MLL occur often as a result of delayed or incorrect diagnosis. Progressive expansion of untreated lesions can cause pressure necrosis of overlying skin. This can result in large areas of skin breakdown and leave underlying fractures exposed [12].

In conclusion, MLL is a rare condition found after a trauma and can lead to infection, skin necrosis, or chronic encapsulated hemolymphatic liquid effusion. This is a rare presentation of MLL with conjunctival chemosis. Diagnosis of MLL can be made on the basis of clinical and radiological examination. Its diagnosis and treatment are often delayed because they involve internal degloving without surface penetration. Image-guided diagnosis and management is a challenge for health facilities in poor settings.

\section{Abbreviations}

MLL: Morel-Lavallée lesion; MRI: Magnetic resonance imaging; WBC: White blood cells; PRBC: Packed red blood cells; US: Ultrasound scan.

\section{Acknowledgements}

Not applicable.

\section{Authors' contributions}

GKB and CKM participated in the design of the case report, acquired data, documented the case, and drafted the manuscript. MM participated in the documentation of the case. All authors read and approved the submitted manuscript.

\section{Funding}

This work received no specific grant from any funding agency in the public, commercial, or not-for-profit sectors.

\section{Declarations}

\section{Ethics approval and consent to participate}

The Ethics Committee of North-Kivu approved the publication of this case.

\section{Consent for publication}

Written informed consent was obtained from the patient's legal guardian(s) for publication of this case report and accompanying images. A copy of the written consent is available for review by the Editor-in-Chief of this journal.

\section{Competing interests}

The author GKB reports support from the Else-Kroner-Fresenius Stiftung through the BEBUC Excellence Scholarship, and KMC reports a grant of the Association for Health Innovation in Africa (AFHIA), a research-based NGO. All the grants reported are outside of the submitted work. The authors declare that they have no competing interests.

\section{Author details}

${ }^{1}$ Department of Surgery, Cliniques Universitaires du Graben, Faculty of Medicine, Université Catholique du Graben, Butembo, Democratic Republic

of Congo. ${ }^{2}$ Department of Infectious Diseases, Faculty of Medicine, Université Catholique du Graben, Butembo, Democratic Republic of Congo. ${ }^{3}$ Department of Paediatrics, Cliniques Universitaires du Graben, Faculty of Medicine, Université Catholique du Graben, Butembo, Democratic Republic of Congo.

Received: 22 October 2019 Accepted: 3 May 2021

Published online: 19 July 2021

\section{References}

1. Morel-Lavallée M. Decollements traumatiques de la peau et des couches sousjacentes. Arch Gen Med. 1863;1:20-38 (172-200, 300-332).

2. Rha EY, Kim DH, Kwon H, Jung SN. Morel-Lavallee lesion in children. World J Emergency Surg. 2013;8:60.

3. Tejwani SG, Cohen SB, Bradley JP. Management of Morel-Lavallee lesion of the knee: twenty-seven cases in the National Football League. Am J Sports Med. 2007:35:1162-7.

4. Mukherjee K, Perrin SM, Hughes PM. Morel-Lavallee lesion in an adolescent with ultrasound and MRI correlation. Skeletal Radiol. 2007;36(Suppl 1):S43-5.

5. Hak DJ, Olson SA, Matta JM. Diagnosis and management of closed internal degloving injuries associated with pelvic and acetabular fractures: the Morel-Lavallee lesion. J Trauma. 1997;42:1046-51.

6. Shen C, Peng JP, Chen XD. Efficacy of treatment in peri-pelvic MorelLavallee lesion: a systematic review of the literature. Arch Orthop Trauma Surg. 2013;133:635-40.

7. Efrimescu Cl, McAndrew J, Bitzidis A. Acute lumbar Morel-Lavallee haematoma in a 14-year-old boy. Emerg Med J. 2012;29:433.

8. Carlson DA, Simmons J, Sando W, Weber T, Clements B. Morel-Lavalee lesions treated with debridement and meticulous dead space closure: surgical technique. J Orthop Trauma. 2007;21:140-4.

9. Anakwenze OA, Trivedi V, Goodman AM, Ganley TJ. Concealed degloving injury (the Morel-Lavallee lesion) in childhood sports: a case report. J Bone Joint Surg Am. 2011;93:148.

10. Mellado JM, Bencardino JT. Morel-Lavallee lesion: review with emphasis on MR imaging. Magn Reson Imaging Clin N Am. 2005;13:775-82.

11. Greenhill D, Haydel C, Rehman S. Management of the Morel-Lavallee lesion. Orthop Clin North Am. 2016;47:115-25.

12. Singh R, Rymer B, Youssef B, Lim J. The Morel-Lavallée lesion and its management: a review of literature. J Orthop. 2018;15:917-21.

\section{Publisher's Note}

Springer Nature remains neutral with regard to jurisdictional claims in published maps and institutional affiliations. 